\title{
STUDYING AND ANALYZE THE FACTORS THAT AFFECT COMPLIANCE DENTIST RECOMMENDATIONS FROM PARENTS OF CHILD PATIENTS
}

DOI: 10.36740/WLek202008127

\author{
Natalia A. Lyakhova, Valentina L. Filatova, Olha V. Sheshukova, Alevtyna M. Bilous, Oleg M. Nesterenko, \\ Valerii V. Bondarenko, Iryna A. Holovanova \\ UKRAINIAN MEDICAL STOMATOLOGICAL ACADEMY, POLTAVA, UKRAINE
}

\begin{abstract}
The aim: Investigate the factors that influence the tendency of parents to follow the advice of a dentist on the way to improving the dental health of their children and build a prognostic model.

Materials and methods: Materials: we analyzed 406 questionnaires (specially created by the author), which contain the answers of parents of schoolchildren of Poltava. Methods: questionnaires, medical and statistical, modeling.

Results: The statistical processing of the questionnaires revealed a number of factors those that affect parents' compliance with the advice of a dentist, increasing or decreasing the chances of it: low sanitary and hygienic awareness of parents; non-observance of hygiene rules by parents; parents do not teach the child to care for the oral cavity; opinion of the parents that only state must take care of children's health; the recommendations of the dentist wasn 't received; child had never visited a dentist for prevention. The operational characteristics of the obtained prognostic model: the area under the curve is 0,762 , which indicates a good predictability of the model. Sensitivity is $82,2 \%$, specificity - $79,8 \%$. Conclusions: The data obtained as a result of our study and the constructed prognostic model: they indicate low sanitary and hygienic awareness of parents, paternalism of their thinking (shifting responsibility to someone, unwillingness to take responsibility), lack of medical and hygienic knowledge, as a result of which they do not apply them to themselves and, of course, to their children. The solution to this problem is possible only through informational and explanatory activities with the involvement of modern methods of communication and people who have passed appropriate training.
\end{abstract}

KEY WORDS: children, dental health, prognostic model.

Wiad Lek. 2020;73(8):1730-1734

\section{INTRODUCTION}

Dental health is an important component of human health, which depends on the balance between the body's ability to adapt to biological, environmental and socio-economic factors, which are risk factors for oral diseases such as dental caries and periodontal disease. The health status of children is a reflection of the impact of biological, environmental and socio-economic factors. Children are especially sensitive to the effects of adverse environmental factors, as their adaptive capacity is reduced compared to adults due to insufficient maturity of the immune, endocrine and nervous systems [1,2].

A number of studies have found of a low levels of dental health in children population. Thus, according to the results of clinical and epidemiological studies, among children from different regions of Ukraine revealed a high prevalence of dental caries - $94,79 \pm 0,62 \%$, at the same time among children of industrially polluted regions it makes $-88,49 \pm 1,57 \%$, in children of a "relatively clean" region with a normal level of fluoride in drinking water $96 \pm 1,39 \%$, and in children living in a fluoride-deficient region $-98,4 \pm 0,48 \%$, with the intensity of caries $-6,44 \pm 3,97$, $4,28 \pm 2,87,5,77 \pm 3,33$ and $8,04 \pm 4,04$ respectively [3].
According to a study by the World Health Organization (WHO), the cause of high prevalence of dental caries is a violation of oral hygiene [4]. Therefore, it is especially important as a regular visit to the child's dentist (not only for treatment but also for preventive purposes), as well as the provision by doctors of professional advice on oral care, preventive measures, nutrition, age characteristics of dental diseases, etc., as well as their careful implementation by patients (under parental supervision) $[5,6]$

It is the responsibility of parents not only to bring the child to the doctor, but also to make an effort to implement these recommendations. Contact of a dentist is an important step for parents in their care for their children's dental health. However, it should be understood that if the dentist's appointment is not followed, the parents do not trust the doctor and do not have the skills of sanitary and hygienic culture in this area, then there is no guarantee that children will be healthy and that they will be instilled with oral care skills from an early age. The need to determine the factors that influence the diligent implementation by parents of the recommendations of the dentist who treats their children, determined the purpose of this study. 
Table I. Factors, which associated with following of the recommendations of the dentist.

\begin{tabular}{|c|c|c|c|c|}
\hline & \multicolumn{2}{|c|}{ Do you follow the advice of a dentist? } & \multirow[b]{2}{*}{$\begin{array}{l}\text { Odds ratio } \\
(95 \% \mathrm{Cl})\end{array}$} & \multirow[b]{2}{*}{$\mathbf{p}$} \\
\hline & $\begin{array}{c}\text { Sometimes, never, advice } \\
\text { was not received, } \\
\text { abs (\%) }\end{array}$ & $\begin{array}{c}\text { Yes, always } \\
\text { follow, } \\
\text { abs (\%) }\end{array}$ & & \\
\hline $\begin{array}{l}\text { Parents have only secondary education, } \\
\qquad n=65\end{array}$ & $\begin{array}{c}20 \\
(30,8)\end{array}$ & $\begin{array}{c}45 \\
(69,2)\end{array}$ & $\begin{array}{c}1,40 \\
(0,78-2,52)\end{array}$ & 0,161 \\
\hline $\begin{array}{l}\text { Profession of parents in the category } \\
\text { of worker, } n=191\end{array}$ & $\begin{array}{c}52 \\
(27,2)\end{array}$ & $\begin{array}{c}139 \\
(72,8)\end{array}$ & $\begin{array}{c}1,24 \\
(0,79-1,93)\end{array}$ & 0,210 \\
\hline $\begin{array}{l}\text { The child's family lives in the city, } \\
\qquad n=394\end{array}$ & $\begin{array}{c}97 \\
(24,9)\end{array}$ & $\begin{array}{c}292 \\
(75,1)\end{array}$ & $\begin{array}{c}0,79 \\
(0,27-2,32)\end{array}$ & 0,431 \\
\hline $\begin{array}{l}\text { Unsatisfactory financial situation } \\
\text { in the family, } n=71\end{array}$ & $\begin{array}{c}21 \\
(29,6)\end{array}$ & $\begin{array}{c}50 \\
(70,4)\end{array}$ & $\begin{array}{c}1,37 \\
(0,75-2,32)\end{array}$ & 0,210 \\
\hline $\begin{array}{l}\text { The age of the child is } 15-18 \text { years, } \\
\qquad n=49\end{array}$ & $\begin{array}{c}14 \\
(28,6)\end{array}$ & $\begin{array}{c}35 \\
(71,4) \\
\end{array}$ & $\begin{array}{c}1,22 \\
(0,63-2,38)\end{array}$ & 0,332 \\
\hline $\begin{array}{l}\text { Poor condition of the oral cavity, } \\
n=48\end{array}$ & $\begin{array}{c}16 \\
(33,3) \\
\end{array}$ & $\begin{array}{c}32 \\
(66,7) \\
\end{array}$ & $\begin{array}{c}1,58 \\
(0,83-3,02) \\
\end{array}$ & 0,113 \\
\hline $\begin{array}{l}\text { Low sanitary and hygienic awareness } \\
\text { of parents, } n=24\end{array}$ & $\begin{array}{c}17 \\
(70,8)\end{array}$ & $\begin{array}{c}7 \\
(29,2)\end{array}$ & $\begin{array}{c}8,49 \\
(3,41-10,14)\end{array}$ & $<0,001$ \\
\hline $\begin{array}{l}\text { The parents did not follow the rules } \\
\text { of hygiene, } n=71\end{array}$ & $\begin{array}{c}34 \\
(47,9)\end{array}$ & $\begin{array}{c}37 \\
(52,1)\end{array}$ & $\begin{array}{c}3,608 \\
(2,11-6,17)\end{array}$ & $<0,001$ \\
\hline $\begin{array}{l}\text { Parents do not teach the child to care } \\
\text { for the oral cavity, } n=9\end{array}$ & $\begin{array}{c}5 \\
(55,6) \\
\end{array}$ & $\begin{array}{c}4 \\
(44,4) \\
\end{array}$ & $\begin{array}{c}4,95 \\
(1,26-8,89) \\
\end{array}$ & 0,023 \\
\hline $\begin{array}{l}\text { The state must take care of children's } \\
\text { health, } n=82\end{array}$ & $\begin{array}{c}28 \\
(34,1)\end{array}$ & $\begin{array}{c}54 \\
(65,9)\end{array}$ & $\begin{array}{c}1,75 \\
(1,04-2,96)\end{array}$ & 0,027 \\
\hline $\begin{array}{l}\text { The recommendations of the dentist } \\
\text { wasn`t received, } n=195\end{array}$ & $\begin{array}{c}77 \\
(39,5) \\
\end{array}$ & $\begin{array}{c}118 \\
(60,5)\end{array}$ & $\begin{array}{c}4,86 \\
(2,93-8,06) \\
\end{array}$ & $<0,001$ \\
\hline $\begin{array}{l}\text { Child had never visited a dentist } \\
\text { for prevention, } n=58\end{array}$ & $\begin{array}{c}9 \\
(15,5) \\
\end{array}$ & $\begin{array}{c}49 \\
(84,5) \\
\end{array}$ & $\begin{array}{c}0,50 \\
(0,24-1,07) \\
\end{array}$ & 0,044 \\
\hline $\begin{array}{l}\text { Dissatisfied with dental care, } \\
\qquad \mathrm{n}=51\end{array}$ & $\begin{array}{c}23 \\
(45,1)\end{array}$ & $\begin{array}{c}28 \\
(54,9)\end{array}$ & $\begin{array}{c}2,87 \\
(1,57-5,26)\end{array}$ & 0,001 \\
\hline $\begin{array}{l}\text { Doctor didn t inform about the rules } \\
\text { of oral hygiene, } n=319\end{array}$ & $\begin{array}{c}87 \\
(27,3)\end{array}$ & $\begin{array}{c}232 \\
(72,7)\end{array}$ & $\begin{array}{c}1,80 \\
(0,98-3,31)\end{array}$ & 0,035 \\
\hline $\begin{array}{l}\text { The child never visited the dentist, } \\
\qquad \mathrm{n}=240\end{array}$ & $\begin{array}{c}74 \\
(30,8) \\
\end{array}$ & $\begin{array}{c}166 \\
(69,2) \\
\end{array}$ & $\begin{array}{c}2,19 \\
(1,35-3,59) \\
\end{array}$ & 0,001 \\
\hline $\begin{array}{l}\text { The child has numerous dental caries, } \\
\qquad \mathrm{n}=225\end{array}$ & $\begin{array}{c}58 \\
(25,8)\end{array}$ & $\begin{array}{c}167 \\
(74,2)\end{array}$ & $\begin{array}{c}1,08 \\
(0,69-1,70)\end{array}$ & 0,412 \\
\hline $\begin{array}{l}\text { The pathology was detected during } \\
\text { a preventive examination, } n=73\end{array}$ & $\begin{array}{c}17 \\
(23,3) \\
\end{array}$ & $\begin{array}{c}56 \\
(76,7) \\
\end{array}$ & $\begin{array}{c}2,38 \\
(0,87-6,52) \\
\end{array}$ & 0,067 \\
\hline $\begin{array}{l}\text { Children who did not visit the dentist } \\
\text { without complaints, } n=118\end{array}$ & $\begin{array}{c}29 \\
(24,6) \\
\end{array}$ & $\begin{array}{c}89 \\
(75,4) \\
\end{array}$ & $\begin{array}{c}1,45 \\
(0,75-2,81) \\
\end{array}$ & 0,175 \\
\hline $\begin{array}{l}\text { Treatment is carried out in the state } \\
\text { polyclinic, } n=130\end{array}$ & $\begin{array}{c}30 \\
(23,1)\end{array}$ & $\begin{array}{c}100 \\
(76,9)\end{array}$ & $\begin{array}{c}1,18 \\
(0,58-2,41)\end{array}$ & 0,397 \\
\hline
\end{tabular}

\section{THE AIM}

Investigate the factors that influence the tendency of parents to follow the advice of a dentist on the way to improving the dental health of their children and build a prognostic model.

\section{MATERIALS AND METHODS}

Materials: we analyzed 406 questionnaires (specially created by the author), which contain the answers of parents of schoolchildren of Poltava. The survey was conducted in schools of Poltava, lasted for 2 months, was anonymous, parents of schoolchildren gave written answers to the questionnaire. The specially created questionnaire consisted of 45 questions, which related to risk factors of dental disease, oral hygiene in children and their parents, the nature of breastfeeding and nutrition of children, factors in the formation of dental health in children and the level of knowledge of their parents, the level of satisfaction with dental care, issues of organization of dental care for children. 
Table II. Prognostic model associated with non-compliance with the advice of a dentist.

\begin{tabular}{|c|c|c|c|c|c|}
\hline \multirow[b]{2}{*}{ Predictors } & \multirow[b]{2}{*}{ B } & \multirow[b]{2}{*}{$\operatorname{Exp}(\beta)$} & \multicolumn{2}{|c|}{ 95\% Cl for EXP(B) } & \multirow[b]{2}{*}{$\mathbf{p}$} \\
\hline & & & Lower & Upper & \\
\hline Failure to follow the rules of oral hygiene & 1,11 & 3,02 & 1,61 & 5,68 & 0,005 \\
\hline The doctor didn 't inform parents about preventive measures & 1,32 & 0,41 & 0,19 & 0,92 & 0,248 \\
\hline Low sanitary and hygienic awareness of parents & 1,03 & 3,52 & 1,28 & 5,69 & 0,015 \\
\hline The state must take care of children's health & $-1,51$ & 0,23 & 0,09 & 0,58 & 0,002 \\
\hline The parents did not receive recommendations from the dentist & $-0,78$ & 4,85 & 2,74 & 5,57 & $<0,001$ \\
\hline The child did not visit the dentist for prophylactic purposes & 0,57 & 1,84 & 1,07 & 3,18 & 0,028 \\
\hline
\end{tabular}

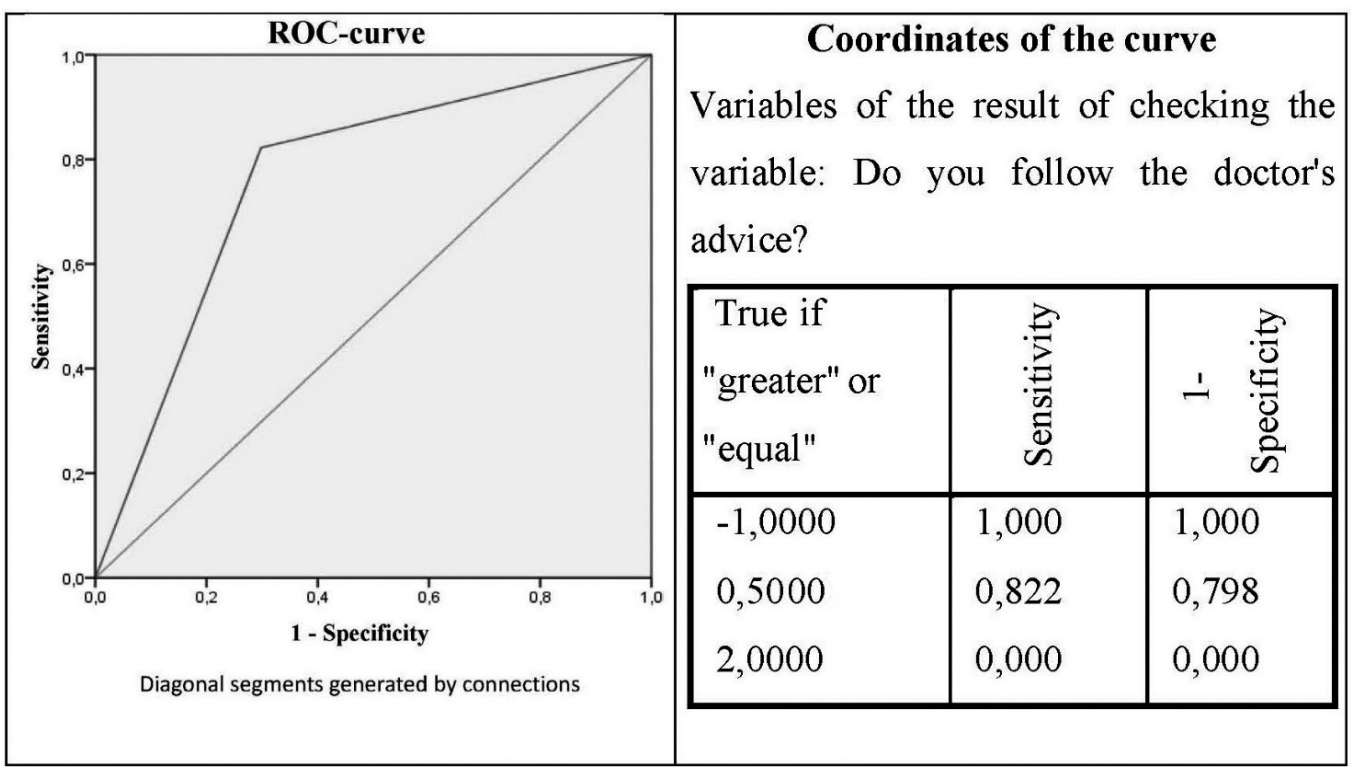

Figure 1. Operational characteristics of the prognostic model associated with non-compliance of the advice of a dentist.
Methods: questionnaires, medical and statistical, modeling. Statistical data processing was performed using statistical programs Microsoft Excel, software package OpenOffice 4.1.3 and statistical package "R".

\section{RESULTS AND DISCUSSION}

By studying and analyzing the results of the survey of parents, we studied various aspects of the subjective opinion of parents about the dental health of their children [7, 8, 9], including those relating to the implementation of the recommendations of the dentist on prevention of dental diseases, observance of oral hygiene, etc. Parents should systematically ( 2 times a year) bring their children to children's dental institutions $[10,11]$. The dentist should give appropriate recommendations for oral care, regarding the implementation of preventive measures, clearly explain the age characteristics of caries and other dental diseases, if necessary, prescribe myogymnastic exercises, massage or physiotherapy procedures to eliminate bad habits, disorders of the formation of the maxillofacial area, warn parents about the possible consequences regarding the negligent attitude to the preservation of dental health. In the treatment of young patients, the communication skills of the dentist play a particularly important role. When working with children of different ages, the doctor must take into account the level of development of the child, plan a special approach to each, do not skimp on encouragement. The ability to establish a trusting relationship with the parents is very important for the further successful treatment of the child [12]. The dentist should also explain to parents the importance of proper nutrition for children's dental health [13].

The statistical processing of the questionnaires by using of the simple logistic regression method revealed a number of factors that affect the dental health of children, including those that affect parents' compliance with the advice of a dentist, increasing or decreasing the chances of it.

Factors that increase the chances of not following of the advice of a dentist, which makes the dental care is ineffective in each case: low sanitary and hygienic awareness (OR 8,49 [95\% CI3,41-10,14]), $\mathrm{p}<0,001$, non-compliance with the rules of oral hygiene (OR 3,61 [95\% CI 2,11-6,17]), $\mathrm{p}<0,001$, the fact that parents do not teach their children for the rules of oral care (OR 4,95 [95\% CI 1,29-8,89]), $\mathrm{p}=0,023$, parents' opinion that the state should take care of dental health (OR 1,75 [95\% CI 1,04-2,96]), $\mathrm{p}=0,027$, not receiving of the appropriate recommendations from the dentist (OR 4,86 [95\% CI 2,93-8,06]), $\mathrm{p}<0,001$, dissatisfaction with the quality of dental care (OR 2,87 [95\% CI $1,57-5,26]), p=0,001$, non-receipt of information from the 
doctor about the observance of sanitary and hygienic rules of the oral cavity (OR 1,80 [95\% CI 0,98-3,31]), $\mathrm{p}=0,035$, and that the child had never visited a dentist for examination and treatment (OR 2,19 [95\% CI 1,35-3,59]), $\mathrm{p}=0,001$. The chances of following the dentist's advice correctly will be reduced in those patients who have indicated that they do not visit the doctor for a preventive examination (OR 0,50 [95\% CI 0,24-1,07]), $\mathrm{p}=0,044$ (Tab. I).

The prognostic model of non-completion of the recommendations of the dentist included the following predictors (tab. II):

- Low sanitary and hygienic awareness of parents

- Non-observance of hygiene rules by parents

- Parents do not teach the child to care for the oral cavity

- Opinion of the parents that only state must take care of children's health

- The recommendations of the dentist wasn 't received

- Child had never visited a dentist for prevention

Predictors that increase risk remain significant in this model:

- The parents did not follow the rules of hygiene: $\operatorname{Exp}(\beta)$ 3,02 (95\% CI 1,61-5,68), $\mathrm{p}=0,005$;

- Low sanitary and hygienic awareness of parents: Exp ( $\beta$ ) 3,52 (95\% CI 2,28-5,49), $p=0,015$;

- The parents did not receive recommendations from the dentist: $\operatorname{Exp}(\beta) 4,85$ (95\% CI 2,74-8,57), $\mathrm{p}<0,001$;

- The child did not visit the dentist for prophylactic purposes: $\operatorname{Exp}(\beta)$ 1,84 (95\% CI 1,07-3,18), $p=0,028$.

According to our model, the risk of not following the doctor's advice increases due to the low sanitary and hygienic awareness of the patient (his parents) and the doctor's neglect to provide preventive advice. At the same time, trust in the doctor grows when the patient believes, that only state must take care of children's health: $\operatorname{Exp}(\beta)$ $0,23$ ( $95 \%$ CI $0,09-0,58), p=0,002$. Such is the imposition of responsibility on the authorities for the child's health, indicates the predominance of the paternalistic model of the relationship between doctor and patient, in accordance with the answers of the patient's parents we interviewed [14]. Paternalism (Paternus (latin) - "parental, paternal") - a system of relations in which the government provides the needs of citizens who in return allow them to dictate patterns of behavior, both public and private. Within the framework of the paternalistic model, the relationship between doctor and patient resembles the parental attitude of parents to the child or the priest to the parishioner. This model shows significant progress in the moral content of the relationship. This is no longer an impersonal manipulation of the subject, which is characteristic of the engineering model of relations. Paternalistic attitude to the patient is filled with subjective content and is built as a kind of interpersonal communication. The moral characteristics of such relationships can be considered love of neighbor, charity, mercy and justice. However, in this model, individuals are in an unequal position. The doctor plays the role of a "father" who has certain scientific knowledge and is able to apply it correctly. The patient plays the role of an inexperienced child, whose moral virtue lies in the disciplined implementation of the prescriptions and appointments of the "elder" person [15].
The operational characteristics of the obtained prognostic model are good. The area under the curve is 0,762 , which indicates a good predictability of the model. Sensitivity is $82,2 \%$, specificity $-79,8 \%$ (Fig. 1 ).

\section{CONCLUSIONS}

The data obtained as a result of our study and the constructed prognostic model quite convincingly confirm the influence of the identified factors on whether the parents of children-patients will follow the advice of the dentist. First of all, they indicate low sanitary and hygienic awareness of parents, paternalism of their thinking (shifting responsibility to someone, unwillingness to take responsibility), lack of medical and hygienic knowledge, as a result of which they do not apply them to themselves and, of course, to their children. The solution to this problem is possible only through informational and explanatory activities, quality sanitary and educational work, which should be organized not formally, but really, with the involvement of modern methods of communication, information technology, social networks and media and people who have passed appropriate training. It is necessary to have a "live" communication between those who teach and those who learn, with the possibility of the latter to express their opinions, ask questions and get answers. The knowledge that will be provided in such work must be modern, structured, understandable, ie designed and presented taking into account the target audience, aimed at motivating of parents to take responsibility for the dental health of their children while explaining what exactly is needed to achieve this goal.

\section{REFERENCES}

1. Khomenko L.0., Ostapko 0.I., Duda 0.V. Ekolohichni aspekty stomatolohichnykh zakhvoriuvan u ditei [Ecological aspects of dental diseases in children]. Klinichna stomatolohiia. 2011; 1-2: 53-63.

2. Natalia A. Lyakhova. Analysis of risk factors of orthodontic pathology: literature review Wiad. Lek. 2018; 71 (5): 1084-1088.

3. Zadorozhna I. V., Povorozniuk V. V. Poshyrenist ta intensyvnist kariiesu zubiv u ditei Ukrainy: rezultaty kliniko-epidemiolohichnoho obstezhennia [Prevalence and intensity of dental caries in children of Ukraine: results of clinical and epidemiological examination]. Problemy osteolohii. 2013; 16 (4): 55-60.

4. Oral Health Programme, Prevention of Noncommunicable DiseasesWHO Headquarters «Ending childhood dental caries: WHO implementation manual». World Health Organization 2019. URL: https://www.who. int/publications/i/item/ending-childhood-dental-caries-whoimplementation-manual

5. Srinivasan Radzh Samuel Shashidhar Acharya, Dzhevika Chandrasekar Rao. School Interventions-based Preven tion of Early-ChildhoodCaries among 3-5-year-old children from very lowsocioeconomic status: Two-year randomized trial. J Public Health Dent. 2019; 80 (1): 51-60.

6. Aleksejūniené Jolanta, Villanueva - Vilchis Maria del Karmen, Anaya - Morales Mónica. A cross-sectional study of the social status of the Mexican caregiver, dental knowledge, self-efficacy and oral health of the caregiver / child. Structural equation model. J Public Health Dent. 2020;80 (2):159-167. 
7. Liakhova N. 0.. Medyko-sotsialne obgruntuvannia optymizovanoi modeli nadannia ortodontychnoi dopomohy dytiachomu naselenniu na rehionalnomu rivni [Medico-social justification of an optimized model for the provision of orthodontic care to the children's population at the regional level]: avtoref. dys. ... kand. med. nauk : 14.02.03. Kharkiv, $2019.25 \mathrm{~s}$

8. Liakhova N. 0. Vyvchennia otsinky batkamy svoiei sanitarnohihiienichnoi obiznanosti ta stanu porozhnyny rota u ditei [Study of parents' assessment of their sanitary and hygienic awareness and the condition of the oral cavity in children]. Poltavski dni hromadskoho zdorovia: materialy nauk.-prakt. konf. z mizhnar. uchastiu (Poltava, 25 travnia 2018 r.). Poltava, 2018: 110-111.

9. Iryna A. Holovanova, Natalia Lyakhova, Olga V. Sheshukova et al. Studying the skills attitudes on factors affecting dental health of children. Wiadomości Lekarskie. 2018; 71 (3 II): 640-647.

10. Nakaz Ministerstva okhorony zdorovia Ukrainy № 682 vid 16.08 .2010 r. "Pro udoskonalennia medychnoho obsluhovuvannia uchniv zahalnoosvitnikh navchalnykh zakladiv" [About improvement of medical service of pupils of comprehensive educational institutions]. URL: https://zakon.rada.gov.ua/laws/show/20794-10.

11. Nakaz Ministerstva okhorony zdorovia Ukrainy № 434 vid 29.11.2002 r." Pro udoskonalennia ambulatorno - poliklinichnoi dopomohy ditiam $\checkmark$ Ukraini" [0n the improvement of outpatient care for children in Ukraine]. URL: https://zakon.rada.gov.ua/rada/show/v0434282-02

12. Padalka A. I., Trufanova V. P., Polishchuk T. V. [et al.]. Communication and interpersonal skills in practice of pediatric dentistry. Svit biolohii ta medytsyny.2018; 2 (64): 213-216.

13. Brittaney Hill. Evaluating the association between food insecurity and dental caries in US children 1-19 years: results from theNational Health and Nutrition Examination Survey (NHANES) 2013-2014. J Public Health Dent. 2019; 80 (1): 14-17.

14. Milena Kravchenko. Sotsialna zakhyshchenist u samootsinkakh naselennia Ukrainy [Social protection in self-appraisal of population in Ukraine]. Derzhavne upravlinnia ta mistseve samovriaduvannia: $z b$. nauk. pr. - Dnipropetrovsk: DRIDU NADU: 61-71.
15. Vytch R. Modeli moralnoi medytsyny v epokhu revoliutsiinykh zmin [Models of moral medicine in the era of revolutionary change]. Pytannia filosofii.1994; 3: 67-72.

Research work "Medico-social substantiation of optimization of approaches to the management and organization of various types of medical care for adults and children in the period of health care reform" (№ state registration 0119U102926).

\section{ORCID and contributionship:}

Natalia A. Lyakhova 0000-0003-0503-9935 A,D,F

Valentina L. Filatova, 0000-0001-5247-1144 ${ }^{E}$

Olha V. Sheshukova, 0000-0002-4739-4890 ${ }^{B}$

Alevtyna M. Bilous, 0000-0001-7379-1577 ${ }^{B, D}$

Oleg M. Nesterenko, 0000-0003-1377-1544 ${ }^{B}$

Valerii V. Bondarenko, 0000-0002-3374-0246 ${ }^{B}$

Iryna A. Holovanova, 0000-0002-8114-8319 C

\section{CORRESPONDING AUTHOR Natalia A. Lyakhova \\ Ukrainian Medical Stomatological Academy \\ Shevchenko 23 str., 36011 Poltava, Ukraine \\ tel: +380506147638 \\ e-mail: NataNew2017@ukr.net}

Received: 10.04 .2020

Accepted: 25.06 .2020

A - Work concept and design, B - Data collection and analysis, C - Responsibility for statistical analysis, $\mathbf{D}$-Writing the article, $\mathbf{E}$-Critical review, $\mathbf{F}$ - Final approval of the article 